\title{
DYNAMIC AND PRESENT IN THE ACCOUNTING TREATMENT APPLIED TO GREEN CERTIFICATES
}

\author{
Sorin-Ciprian Teiuşan \\ Ionela Cornelia Cioca ${ }^{2}$
}

\begin{abstract}
Green certificates are documents attesting production from renewable energy sources of a quantity of electricity. They are issued monthly by the transmission and system operator for electricity producers who use renewable energy and are traded on the green certificates market, electricity providers and producers being required to purchase quarterly a number of green certificates appropriate to the amount of electricity supplied to final consumers quarterly. Purpose of this paper is to analyze the accounting treatment of green certificates in terms of current accounting regulations and changes occurred in relation to greenhouse gas emission certificates. The research results are translated into highlighting the accounting approach for green certificates for electricity producers from renewable energy sources, who benefit from these titles, as well as for the providers and producers of electricity required to purchase green certificates.
\end{abstract}

Key words: green certificates; greenhouse gas emission certificates; accounting branch; analyze; accounts.

JEL Codes: M41; Q40; Q56

\section{Introduction}

In 2001 RECS was created (Renewable Energy Certificate System), an international organization related to the system of certificates of energy from renewable sources, whose goal is to create a harmonized market for green certificates (Bețianu, 2009).

At EU level there are two schemes to promote renewable energy:

- Fixed price system, which consists in the acquisition by producers, suppliers or consumers of renewable energy sources at a fixed price, the value of which is determined by renewable source of used energy;

- Mandatory annual quota system, combined with green certificates system, under which governments establish renewable energy share to be purchased by producers, suppliers and consumers, the purchase price being set on the market.

In Romania there operates a system of promotion of electricity produced from renewable energy sources, established by Law no. 220/2008, in the category of renewable energy sources being included: non-fossil energy sources, namely: wind, solar, aero thermal, geothermal, hydrothermal and ocean energy, hydropower, biomass, landfill gas, also called gas deposit and sludge digester gas from wastewater treatment plants and biogas. The promotion system includes, but is not limited to the promotion system of green certificates, investment aid, tax exemptions or reductions, tax refunds, promotion schemes on the obligation to purchase energy from renewable sources.

What are green certificates? And the green certificate promotion system?

Green certificate is a title which certifies production of a quantity of electricity from renewable energy sources. It has the following features:

\footnotetext{
${ }^{1} 1$ Decembrie 1918 University, Alba Iulia, Romania, e-mail: ciprian.teiusan@uab.ro
}

${ }^{2} 1$ Decembrie 1918 University, Alba Iulia, Romania, e-mail: cioca.ionela@uab.ro, 
- it is issued electronically, it is recorded in the issue register and the information is transmitted to the accredited economic operator and to green certificates market operator;

- it contains at least the name and address of the accredited economic operator, renewable energy source type used, the license number of commercial exploitation of production capacity, if any, and the accreditation decision of the Romanian Energy Regulatory Authority, serial number, identification number, issuer and issue date;

- it has as a maximum validity of 16 months from the date of issue, after which it is canceled if not used by a supplier to prove the fulfillment of the mandatory quota of green certificates acquisition, in which case it is considered used green certificate (ANRE President Order no. 43/2011, art. 14).

The certificate promotion system means a mandatory quota system, i.e. a mechanism promoting electricity from renewable energy sources by applying mandatory annual purchase quotas of purchase of green certificates (the purchase share of green certificates required annually to power energy suppliers), combined with green certificates trading. To benefit from the green certificates promotion system, the Romanian Energy Regulatory Authority (ANRE) accredit the producers of electricity from renewable energy sources, as provided in the Rules of accreditation of producers of electricity from renewable energy sources to apply the green certificates promotion system (Law no. 220, art. 2, 4). To obtain green certificates, accredited economic operators enroll to transmission and system operator upon request, made in writing and / or electronically, to which it is attached a copy of the accreditation decision issued by ANRE and a copy of commercial operating license of the capacity of producing electricity from renewable energy sources.

Transmission and system operator (the person who has, in any way, an electricity transmission network and holds a transmission license which is responsible for operating, ensuring the maintenance of and, if necessary, developing the transmission system in a given area and, where applicable, interconnection with other power systems, and for ensuring the long term ability of the system to meet reasonable demands for electricity transmission - Law no. 123/2012, art. 3), represented by National Company of Power Transmission "Transelectrica" - SA, issues green certificates monthly to producers for the amount of electricity produced from power plants using renewable energy sources, from which the amount of electricity needed to ensure their own technological consumption is reduced. The number of green certificates issued monthly to an accredited economic operator is determined as product between the amount of electricity produced from renewable energy sources and the number of green certificates which, the economic operator, depending on the type of technology, should receive for each $1 \mathrm{MWh}$ produced and delivered to the power grid and / or to the consumer. The number of green certificates which the producers of renewable energy for produced and delivered electricity would benefit from, is determined by legal requirements they fulfilled, by criteria such as: type of used renewable sources, plant capacity and its technology (central, new or refurbished), analysis year. For the electricity produced in power plants / cogeneration units which use geothermal energy, biomass, bio liquids, biogas, landfill gas, sludge digester gas from wastewater treatment facilities and qualified by ANRE as highly efficient, additional green certificates are given (ANRE President Order no. 43/2011, art. 3, 11).

On the other hand, electricity suppliers and producers are required to purchase quarterly a number of green certificates equivalent with the value of annual mandatory quota of green certificates of acquisition set for the year and the amount of energy, expressed in MWh, provided quarterly to final consumers. The amount of electricity for which the obligation to purchase green certificates is established, includes: electricity purchased by electricity suppliers, for both their final consumption and sale to final consumers; electricity used for own final consumption, other than own technology consumption, by an electricity producer; electricity used by a producers to supply electricity to consumers connected by direct line of power plant (Law no. 220/2008, art. 6, 8). In addition to issuing green certificates for accredited operators, another requirement of transmission 
and system operator is to keep register of the beneficiaries of the green certificates and issued green certificates (ANRE President Order no. 43/2011, art. 5).

The calculation method of the amount of electricity produced from renewable energy sources beneficial to green certificates promotion system, green certificates issuing mode, as well as the parties involved and their responsibilities in the process of issuing green certificates are laid down in Regulation issuance of green certificates, approved by Order of the President of the Romanian Energy Regulatory Authority no. 43/2011.

Producers of electricity from renewable energy sources and electricity suppliers trade green certificates on the green certificates market, a competitive market, separated from the electricity market, consists of two components, namely:

- green certificates centralized market, the organized framework of developing trading of green certificates among market participants, managed by the company "Electricity Market Operator - OPCOM" - SA, based on specific rules approved by ANRE, and

- bilateral contracts market for green certificates, represented by all bilateral agreements negotiated between green certificates market participants for the sale and purchase of green certificates (ANRE President Order no. 44/2011, art. 3, 5).

In early November 2011, there entered into force ANRE President Order no. 44 for approving the Rules of the organization and functioning of the green certificates market, bill establishing the organization and functioning mode of the green certificates market, stakeholders and their responsibilities in the organization and operation of green certificates market, the mode of registering and managing the information relating to trading green certificates and the information necessary to monitor the functioning of green certificates. Related to trading green certificates, Dunel-Stancu (2011) noted that: "such transactions with green certificates are done on a regulated market of domestic special rules, rules that are about to become effectively functional, although there are still short-circuiting that make green energy investors to wonder if they make a safe and profitable investment or not. Waiting for the implementing regulations, at the moment, the main actors enjoy, finally, after years of waiting, the green certificates support scheme adopted and approved by the state". The actors are ANRE, the producers of electricity from renewable energy sources, suppliers, transmission and system operator and OPCOM.

The price of green certificates varies within [Pmin $\div$ Pmax] established by Government Decision. Minimum price is required to protect producers and the maximum price to protect consumers. For the 2008-2014 period the trading value of green certificates ranges from a minimum trading value of 27 euro/certificate and a maximum trading value of 55 euro/certificate. The value in lei is calculated at the average exchange rate set by the National Bank of Romania for December of the previous year (www.opcom.ro).

\section{Objectives and Research Methodology}

How is accounting management of green certificates in Romania performed? What are the accounts used for keeping the accounts of these titles? The purpose of this paper is the analysis of green certificates accounting treatment to be applied to electricity producers from renewable energy sources, benefiting from green certificates, as well as suppliers and electricity producers obligated to purchase green certificates. To achieve our aims, we resorted to examining the following acts:

- Law no. 220/2008 on establishing the promotion system of energy production from renewable energy sources, as amended and supplemented;

- Government Decision no. 780/2006 regarding the establishment of greenhouse gas emission allowance trading, as amended and supplemented;

- Minister of Public Finance Order no. 3055/2009 for the approval of accounting Regulations with European Directives, amended and supplemented; 
- Order of the President of the Romanian Energy Regulatory Authority no. 43/2011 for approval of the issuance of green certificates;

- Order of the President of the Romanian Energy Regulatory Authority no. 44/2011 approving the Regulation on organization and operation of green certificates market.

Towards achieving the purposes, in this article we used, as the main research methods, the following: qualitative analysis, within it, the comparison method being found, a method aimed at obtaining perceptual differences between the accounting treatment of green certificates and accounting treatment of greenhouse gas emission certificates; synthesis: found in establishing conclusions aimed at explaining and assessing the situation found, documentation as theoretical research method in which we included specialized accounting literature in the field of green certificates and regulations in force, and case study method used in the accounting treatment of green certificates for renewable energy producers as well as for suppliers and electricity producers obliged to purchase green certificates.

\section{Literature Review}

Literature in the accounting treatment of green certificates is "poor" in publications. Leontina Bețianu (2009), in her work called "Total quality in environmental accounting" she deals with the issue of green certificates from both technical and accounting point of view. With regard to the accounting treatment of green certificates, the author presents two views:

- Belgian Electrabel Group states that green certificates are recorded in tangible assets at acquisition cost if they were purchased, and at market price if they are obtained from the production of energy from renewable sources, in correspondence with an account of income. At the same time, a liability for the estimated amount of green certificates held is recognized. This debt is valued at weighted average cost of acquisition of certificates obtained, which were internally generated or purchased at market price for certificates that group does not own;

- Finnish Stora Enso Group presents the information in the explanatory notes on the revenue from green certificates, not being specified any information on how to deal with them.

The author makes the following statement: "from the specified data it is observed that the information presented is not uniform, due to the lack of rules governing this. In these conditions, more accounting treatments are acceptable, but once the choice is made, the accounting treatment should be applied consistently, and in the explanatory notes to the financial statements, the accounting policies must be disclosed. This information is important for users and, therefore, adopting a uniform rule to reflect these issues is required"(Bețianu, 2009).

In Romania, "up to August 2012, green certificates were not covered specifically in accounting legislation, fact for which accountants could encounter difficulties in relation to the tax authorities when discussing the taxation of income generated by their record to producers of renewable energy, difficulties starting from different interpretations of the accounting treatment which could have been applied to green certificates" (Ramona Sandu, Accounting Manager at Accace, cited by Garaiman, 2013).

In August 2012, the Minister of Public Finance Order no. 1118 appears, for the amendment of Accounting Regulations approved by the Minister of Public Finance no. 3055/2009, law that changes the recording method in accounting of green certificates by introducing in Section 8.3.3. "Short-term investments", of a subsection called "Accounting for green certificates". Until the entry into force of this Order, the green certificates have been treated in accounting terms as greenhouse gas emission certificates. The greenhouse gas emission certificate is a title which gives the right to release into the atmosphere a ton of carbon dioxide equivalent in a defined period (Government Decision no. 780/2006, art. 3). "However, considering the operation of the system of green certificates, a distinct accounting treatment was instituted for them" (KPMG Advisory Newsflash no. 141). 
Analyzing the proposals of legislation and accounting rules Directorate of the Ministry of Finance, with respect to green certificate operations, Staicu (2012) noted, "the draft order provides that the green certificates received, according to the law, by operators are treated as short-term investments and have the accounting treatment prescribed for this asset class".

Examining the Minister of Public Finance Order no. 1118/2012, Benta (2012) considers that the legislative act "covers mainly recording in the accounting records and accounts used for the purchase, reception and transfer for free and allowances of emission certificates in the atmosphere".

Neagu (2012) reviews a number of new accounting rules applicable to the 2013 annual financial statements, including those regarding the accounting treatment of green certificates.

Pântea and Bodea (2013) present in their book the accounting records with green certificates, using examples for electricity producers from renewable energy sources, and for the electricity providers.

\section{Analyses and Results}

In 2009, the Ministry of Public Finance issued Order no. 3055, approving the accounting regulations compliant with European Directives bill introducing in the general chart of accounts, for entities applying Accounting Regulations in accordance with Directive IV of the European Economic Community, two synthetic three-digit accounts specific to accounting of items related to environment, one in class 6 "Expense accounts" and the other in class 8 "Special accounts", namely:

- account 652 "Expenses related to environment protection" included in group 65 "Other operating expenses" for reflecting the costs related to environmental protection, for the period, resulting in environmental taxes paid and greenhouse gas emission certificates acquired under the legislation in force and used, whose costs can be determined, related to the current period, and

- account 806 "Greenhouse gas emission certificates", which belongs to group 80 "Off balance sheet accounts", for highlighting the greenhouse gas emission certificates received for free, by law, which has no set value and, therefore, cannot be recognized in balance sheet accounts.

Also section 227 of the Accounting Regulations compliant with Directive IV of the European Economic Community requires the inclusion, actually, in the category of provisions shown in the balance sheet to "Other provisions" of the provision for expenses related to environmental protection, for: air protection; wastewater management; waste management; soil, groundwater and surface water protection; biodiversity and landscape protection; other environmental protection activities.

In 2012, the Minister of Public Finance Order no. 1118 appears which amends the Minister of Public Finance Order no. 3055/2009, establishing a new accounting treatment for green certificates received from operators. If by that time, the accounting treatment of green certificates was similar to the treatment which was applied to greenhouse gas emission certificates, from the financial statements for 2012, green certificates are treated as short-term investments and have the accounting treatment prescribed for this category of assets. "The novelty brought by this order is that green certificates will be treated as short-term investments, given that the Law 220/2008 - with amendments and completions - shows that certificates have a duration of 16 months and a minimum and maximum trading value in euro." (Bărbătescu, 2012)

Analysis of several articles that discuss accounting of green certificates highlighted in some cases confusion between green certificates and greenhouse gas emission certificates. These titles may not be included in the same category and treated similarly, with the major differences between them, from the definition of the two categories of documents and continuing with the entities that manage them and regulating authorities of their circuit in the national economy. In an article entitled "On green certificates, clean air and money in the wind" Dunel-Stancu (2011) explains the difference between green certificates and greenhouse gas emission certificates, concluding: "even if it is still about fresh air, green grass and crystal clear waters, the suspension of Romania's right to 
assert the units of greenhouse effect gas, allocated from national pollution assessment, has nothing to do with trading and use of green certificates. What really helps to make this distinction? It is not known exactly, but it makes us look objectively in the authorities' courtyard and to better understand why bread is expensive again".

To achieve the goal of the research, in the following, we are presenting a comparative analysis of records of transactions with green certificates based on the accounting treatment prescribed by the authors which studied this issue. To do this, we organize data into a tabular situation that would allow us emphasize accounting formulas for each operation. We specify that, before the appearance in 2013, at Intelcredo Publishing House, of the book entitled Financial Accounting, written by teachers Pântea and Bodea, in any academic journal or any international database there was no work on the subject, the only articles we have used regarding the accounting of green certificates are retrieved from the Internet: Bărbătescu (2012), Benta (2012) and Neagu (2013).

The comparative analysis of the accounting treatment of green certificates allows us to formulate the following considerations:

a) All authors present distinct accounting treatment applied to green certificates for electricity producers from renewable energy sources, electricity suppliers and entities who buy green certificates in order to obtain short-term gains;

b) For electricity producers from renewable energy sources, the main operations are:

- receiving green certificates: all authors use account 508 "Other short-term investments" in the correspondence with account 472 "Accrued income". One of them is confusing green certificates with emission certificates; we explain above the difference between them;

- sale of green certificates: some authors use account 4111 "Customers", others account 461 "Sundry debtors", in coresspondence with account 758 "Other operating incomes" or 764 "Incomes from financial investments", recording discharge of green certificates sold togheter with the sale or distinct, in last situation using account 652 "Expenses related to environment protection" or 664 "Expenses with financial investments";

- recording revenues for the sale of green certificates on the price of their receipt: authors use account 472 "Accrued income" in correspondence with accounts 768 "Other financial incomes", 764 "Incomes from financial investments", 708 „Incomes from other activities”. There are different points of view because the accounting regulations do not cleary states the account that must be used to record this income;

- evaluation of green certificates at the end of the financial year is the same in all four variants: account 508 "Other short-term investments" in correspondence with account 668 "Other financial expenses" for unfavorable differences or account 768 "Other financial incomes" for favorable differences;

- Pântea and Bodea (2013) also present the accounting treatment applies to green certificates unsold in validity period (6 months).

c) For electricity suppliers, the authors record in accounting the following operations with green certificates:

- acquisition of green certificates: account 652 "Expenses related to environment protection" in correspondence with account 401 "Suppliers" or account 508 "Other short-term investments" in correspondence with account 401 "Suppliers" and 652 "Expenses related to environment protection" in correspondence with account 508 "Other short-term investments";

- acquisition of green certificates before legal time limits is the same in all four options: account 471 "Prepayments" in correspondence with account 401 "Suppliers". 
Table no. 1

A comparative analysis on the accounting treatment of green certificates

\begin{tabular}{|c|c|c|c|c|}
\hline Explanations & $\begin{array}{c}\text { Accounting treatment } \\
\text { (Bărbătescu, 2012) }\end{array}$ & $\begin{array}{c}\text { Accounting treatment } \\
\text { (Benta, 2012) }\end{array}$ & $\begin{array}{c}\text { Accounting treatment } \\
(\text { Neagu, 2013) }\end{array}$ & $\begin{array}{c}\text { Accounting treatment } \\
\text { (Pântea and Bodea, 2013) }\end{array}$ \\
\hline \multicolumn{5}{|c|}{ Electricity producers from renewable energy sources } \\
\hline $\begin{array}{l}\text { Receiving green } \\
\text { certificates }\end{array}$ & $\begin{array}{l}\mathbf{5 0 8} \text { "Other short-term } \\
\text { investments"/ analytical green } \\
\text { certificates = } \\
\mathbf{4 7 2} \text { "Accrued income"/ analytical } \\
\text { green certificates }\end{array}$ & $\begin{array}{l}\mathbf{5 0 8} \text { "Other investments - } \\
\text { analytical emission certificates" = } \\
\mathbf{4 7 2} \text { "Accrued income" }\end{array}$ & $\begin{array}{l}\mathbf{5 0 8} \text { "Other short-term } \\
\text { investments and related } \\
\text { receivables"/ analytical distinct = } \\
\mathbf{4 7 2} \text { "Accrued income"/ analytical } \\
\text { distinct }\end{array}$ & $\begin{array}{l}\mathbf{5 0 8 1} \text { "Other short-term } \\
\text { investments" = } \\
\mathbf{4 7 2} \text { "Accrued income" }\end{array}$ \\
\hline $\begin{array}{l}\text { Sale of green } \\
\text { certificates } \\
\text { at a price higher } \\
\text { than accounting } \\
\text { value }\end{array}$ & $\begin{array}{l}4111 \text { "Customers" = } \\
\mathbf{7 5 8} \text { "Other operating incomes" }\end{array}$ & $\begin{array}{l}\mathbf{4 1 1 1} \text { "Customers" = } \\
\mathbf{7 6 4} \text { "Incomes from financial } \\
\text { investments" }\end{array}$ & - & $\begin{array}{l}\mathbf{4 6 1} \text { "Sundry debtors" = } \\
\% \\
\mathbf{5 0 8 1} \text { "Other short-term } \\
\text { investments" } \\
\mathbf{7 6 4 2} \text { "Gains on disposal of short- } \\
\text { term investments" }\end{array}$ \\
\hline $\begin{array}{l}\text { Sale of green } \\
\text { certificates } \\
\text { at a price less than } \\
\text { accounting value }\end{array}$ & 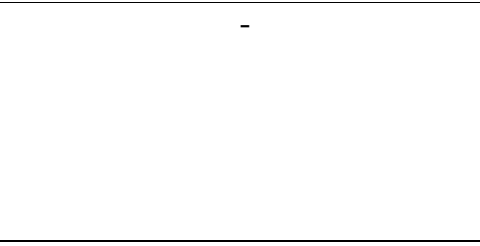 & 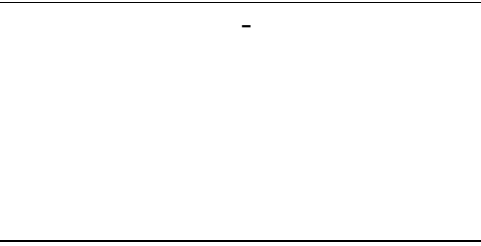 & - & $\begin{array}{l}\% \\
\mathbf{4 6 1} \text { "Sundry debtors" } \\
\mathbf{6 6 4 2} \text { "Losses on disposal of } \\
\text { short-term investments" } \\
=\mathbf{5 0 8 1} \text { "Other short-term } \\
\text { investments" }\end{array}$ \\
\hline $\begin{array}{l}\text { Discharge of green } \\
\text { certificates sold }\end{array}$ & $\begin{array}{l}\mathbf{6 5 2} \text { "Expenses related to } \\
\text { environment protection" = } \\
\mathbf{5 0 8} \text { "Other short-term } \\
\text { investments"/ analytical green } \\
\text { certificates }\end{array}$ & $\begin{array}{l}\mathbf{6 6 4} \text { "Expenses with financial } \\
\text { investments" = } \\
\mathbf{5 0 8} \text { "Other investments - } \\
\text { analytical emission certificates" }\end{array}$ & - & - \\
\hline $\begin{array}{l}\text { Recording } \\
\text { revenues for the } \\
\text { sale of green } \\
\text { certificates on the } \\
\text { price of their } \\
\text { receipt }\end{array}$ & $\begin{array}{l}472 \text { "Accrued income" = } \\
\mathbf{7 6 8} \text { "Other financial incomes" }\end{array}$ & $\begin{array}{l}472 \text { "Accrued income" = } \\
\mathbf{7 6 4} \text { "Incomes from financial } \\
\text { investments" }\end{array}$ & $\begin{array}{l}\text { Accrued income become revenues } \\
\text { recorded in the profit and lose } \\
\text { account when the green } \\
\text { certificates are sold }\end{array}$ & $\begin{array}{l}\mathbf{4 7 2} \text { "Accrued income" = } \\
\mathbf{7 0 8} \text {,Incomes from other } \\
\text { activities" }\end{array}$ \\
\hline $\begin{array}{l}\text { Discharge of green } \\
\text { certificates sold }\end{array}$ & $\begin{array}{l}652 \text { "Expenses related to } \\
\text { environment protection" = }\end{array}$ & $\begin{array}{l}\mathbf{6 6 4} \text { "Expenses with financial } \\
\text { investments" = }\end{array}$ & - & - \\
\hline
\end{tabular}




\begin{tabular}{|c|c|c|c|c|}
\hline & $\begin{array}{l}\mathbf{5 0 8} \text { "Other short-term } \\
\text { investments"/ analytical green } \\
\text { certificates }\end{array}$ & $\begin{array}{l}\mathbf{5 0 8} \text { "Other investments - } \\
\text { analytical emission certificates" }\end{array}$ & & \\
\hline $\begin{array}{l}\text { Evaluation of green } \\
\text { certificates at the } \\
\text { end of the financial } \\
\text { year to a value less } \\
\text { than the accounting } \\
\text { value }\end{array}$ & $\begin{array}{l}\mathbf{6 6 8} \text { "Other financial expenses" = } \\
\mathbf{5 0 8} \text { "Other short-term } \\
\text { investments"/ analytical green } \\
\text { certificates }\end{array}$ & $\begin{array}{l}\mathbf{6 6 8} \text { "Other financial expenses" = } \\
\mathbf{5 0 8} \text { "Other investments - } \\
\text { analytical emission certificates" }\end{array}$ & $\begin{array}{l}\mathbf{6 6 8} \text { "Other financial expenses" = } \\
\mathbf{5 0 8} \text { "Other short-term } \\
\text { investments and related } \\
\text { receivables"/ analytical distinct }\end{array}$ & $\begin{array}{l}\mathbf{6 6 8} \text { "Other financial expenses" = } \\
\mathbf{5 0 8 1} \text { "Other short-term } \\
\text { investments" }\end{array}$ \\
\hline $\begin{array}{l}\text { Evaluation of green } \\
\text { certificates at the } \\
\text { end of the financial } \\
\text { year to a value } \\
\text { higher than the } \\
\text { accounting value }\end{array}$ & $\begin{array}{l}\mathbf{5 0 8} \text { "Other short-term } \\
\text { investments"/ analytical green } \\
\text { certificates = } \\
\mathbf{7 6 8} \text { "Other financial incomes" }\end{array}$ & $\begin{array}{l}\mathbf{5 0 8} \text { "Other investments - } \\
\text { analytical emission certificates" = } \\
\mathbf{7 6 8} \text { "Other financial incomes" }\end{array}$ & $\begin{array}{l}\mathbf{5 0 8} \text { "Other short-term } \\
\text { investments and related } \\
\text { receivables"/ analytical distinct = } \\
\mathbf{7 6 8} \text { "Other financial incomes" }\end{array}$ & $\begin{array}{l}\mathbf{5 0 8 1} \text { "Other short-term } \\
\text { investments" = } \\
\mathbf{7 6 8} \text { "Other financial incomes" }\end{array}$ \\
\hline $\begin{array}{l}\text { Canceling unsold } \\
\text { green certificates in } \\
\text { validity period }\end{array}$ & - & - & - & $\begin{array}{l}\mathbf{6 6 8} \text { "Other financial expenses" = } \\
\mathbf{5 0 8 1} \text {,Alte titluri de plasament" } \\
\mathbf{4 7 2} \text { "Accrued income" = } \\
\mathbf{7 0 8} \text {,Incomes from other } \\
\text { activities" }\end{array}$ \\
\hline \multicolumn{5}{|c|}{ Electricity suppliers } \\
\hline $\begin{array}{l}\text { Acquisition of } \\
\text { green certificates }\end{array}$ & $\begin{array}{l}\mathbf{6 5 2} \text { "Expenses related to } \\
\text { environment protection" = } \\
\mathbf{4 0 1} \text { "Suppliers" }\end{array}$ & $\begin{array}{l}\mathbf{5 0 8} \text { "Other investments - } \\
\text { analytical emission certificates" = } \\
\mathbf{4 0 1} \text { "Suppliers" } \\
\mathbf{6 5 2} \text { "Expenses related to } \\
\text { environment protection" = } \\
\mathbf{5 0 8} \text { "Other investments - } \\
\text { analytical emission certificates" }\end{array}$ & $\begin{array}{l}\mathbf{6 5 2} \text { "Expenses related to } \\
\text { environment protection" = } \\
\mathbf{4 0 1} \text { "Suppliers" }\end{array}$ & $\begin{array}{l}\text { 652 "Expenses related to } \\
\text { environment protection" = } \\
\mathbf{4 0 1} \text { "Suppliers" }\end{array}$ \\
\hline $\begin{array}{l}\text { Acquisition of } \\
\text { green certificates } \\
\text { before legal time } \\
\text { limits, }\end{array}$ & $\begin{array}{l}471 \text { "Prepayments" = } \\
\mathbf{4 0 1} \text { "Suppliers" } \\
\mathbf{6 5 2} \text { "Expenses related to }\end{array}$ & $\begin{array}{l}\mathbf{4 7 1} \text { "Prepayments" = } \\
\mathbf{4 0 1} \text { "Suppliers" } \\
\mathbf{6 5 2} \text { "Expenses related to }\end{array}$ & $\begin{array}{l}\mathbf{4 7 1} \text { "Prepayments" = } \\
\mathbf{4 0 1} \text { "Suppliers" } \\
\mathbf{6 5 2} \text { "Expenses related to }\end{array}$ & - \\
\hline
\end{tabular}




\begin{tabular}{|c|c|c|c|c|}
\hline $\begin{array}{l}\text { and in legal time } \\
\text { limits }\end{array}$ & $\begin{array}{l}\text { environment protection" = } \\
\mathbf{4 7 1} \text { "Prepayments" }\end{array}$ & $\begin{array}{l}\text { environment protection" = } \\
\mathbf{4 7 1} \text { "Prepayments" }\end{array}$ & $\begin{array}{l}\text { environment protection" = } \\
\mathbf{4 7 1} \text { "Prepayments" }\end{array}$ & \\
\hline $\begin{array}{l}\text { Payment of green } \\
\text { certificates }\end{array}$ & - & - & - & $\begin{array}{l}401 \text { "Suppliers" = } \\
\mathbf{5 1 2 1} \text { "Cash at bank in lei" }\end{array}$ \\
\hline \multicolumn{5}{|c|}{ Acquisition of green certificates by entities in order to obtain short-terms gains } \\
\hline $\begin{array}{l}\text { Acquisition of } \\
\text { green certificates }\end{array}$ & $\begin{array}{l}\mathbf{5 0 8} \text { "Other short-term } \\
\text { investments"/ analytical green } \\
\text { certificates = } \\
\mathbf{4 0 1} \text { "Suppliers" }\end{array}$ & - & $\begin{array}{l}\mathbf{5 0 8} \text { "Other short-term } \\
\text { investments and related } \\
\text { receivables"/ analytical distinct = } \\
\mathbf{4 0 1} \text { "Suppliers" }\end{array}$ & $\begin{array}{l}\mathbf{5 0 8 1} \text { "Other short-term } \\
\text { investments" = } \\
\mathbf{5 0 9 2} \text { "Amounts payable for other } \\
\text { short term investments" }\end{array}$ \\
\hline $\begin{array}{l}\text { Payment of green } \\
\text { certificates }\end{array}$ & - & - & - & $\begin{array}{l}\mathbf{5 0 9 2} \text { "Amounts payable for ither } \\
\text { short term investments" = } \\
\mathbf{5 1 2 1} \text { "Cash at bank in lei" }\end{array}$ \\
\hline $\begin{array}{l}\text { Sale of green } \\
\text { certificates at a } \\
\text { price higher than } \\
\text { acquisition price }\end{array}$ & - & - & & $\begin{array}{l}\mathbf{4 6 1} \text { "Sundry debtors" = } \\
\% \\
\mathbf{5 0 8 1} \text { "Other short-term } \\
\text { investments" } \\
\mathbf{7 6 4 2} \text { "Gains on disposal of short- } \\
\text { term investments" }\end{array}$ \\
\hline $\begin{array}{l}\text { Sale of green } \\
\text { certificates at a } \\
\text { price less than } \\
\text { acquisition price }\end{array}$ & - & - & - & $\begin{array}{l}\mathbf{5 0 8 1} \text { "Other short-term } \\
\text { investments" = } \\
\% \\
\mathbf{4 6 1} \text { "Sundry debtors" } \\
\mathbf{6 6 4 2} \text { "Losses on disposal of } \\
\text { short-term investments" }\end{array}$ \\
\hline $\begin{array}{l}\text { Receivables } \\
\text { turnover }\end{array}$ & ( & - & ( & $\begin{array}{l}\mathbf{5 1 2 1} \text { "Cash at bank in lei" = } \\
\mathbf{4 6 1} \text { "Sundry debtors" }\end{array}$ \\
\hline $\begin{array}{l}\text { Cancelling unused } \\
\text { green certificates in } \\
\text { validity period }\end{array}$ & $\begin{array}{l}\mathbf{6 6 8} \text { "Other financial expenses" = } \\
\mathbf{5 0 8} \text { "Other short-term } \\
\text { investments"/ analytical green } \\
\text { certificates }\end{array}$ & - & $\begin{array}{l}\mathbf{6 6 8} \text { "Other financial expenses" = } \\
\mathbf{5 0 8} \text { "Other short-term } \\
\text { investments and related } \\
\text { receivables"/ analytical distinct }\end{array}$ & - \\
\hline
\end{tabular}

Source: processing of data from the literature was conducted by the authors 
d) About acquisition of green certificates by entities in order to obtain short-terms gains, the operations are:

- acquisition of green certificates: account 508 "Other short-term investments" in correspondence with account 401 "Suppliers" or account 5092 "Amounts payable for other short term investments";

- payment of green certificates, sale of green certificates and receivables turnover are presented only by Pântea and Bodea (2013);

- cancelling unused green certificates in validity period: account 668 "Other financial expenses" in correspondence with account 508 "Other short-term investments" (Bărbătescu, 2012; Neagu, 2013).

In conclusion, in all four variants the research showed some differences to a few income accounts, resulted from a missing explanation in accounting regulations, which not affect the financial position and performance position of the entities involved on the market of green certificates.

In this context, the research requires a careful analysis of accounting regulations in force relating to the accounting of green certificates, but also the previous accounting rules in the context of the dynamics of accounting. Before 2009, when the Ministry of Public Finance issued Order no. 3055 , no other previous regulations have mentioned anything about green certificates or emission certificates. In the last few years has been constituted the green certificates market and all entities involved on this market needed instruments to record in accounting the green certificates that receive, buy or sell. The accounting regulations have been modified to answer to these requirements. Analyzing the national accounting regulations showed us the accounts that must be used: 5081 "Other short-term investments / analytical green certificates", 472 "Accrued income / analytical green certificates", 768 "Other financial incomes", 668 "Other financial expenses", 652 "Expenses related to environment protection", 471 "Prepayments". But these accounts are not enough to complete all the records in accounting. The accountant needs more detailed information, which can not be found in Romanian accounting regulations. Therefore there are differences between the authors' opinions for the treatment applied to green certificates.

In what follows, we will focus on the accounting treatment of green certificates both for electricity producers from renewable energy sources, for electricity providers and for entities who buy green certificates in order to obtain short-term gains.

A. The accounting treatment of green certificates applicable to electricity producers from renewable sources

1. In August 2012, SC Energoplus SA receives from SC OPCOM SA 250 green certificates at a value of 240.86 lei/certificate:

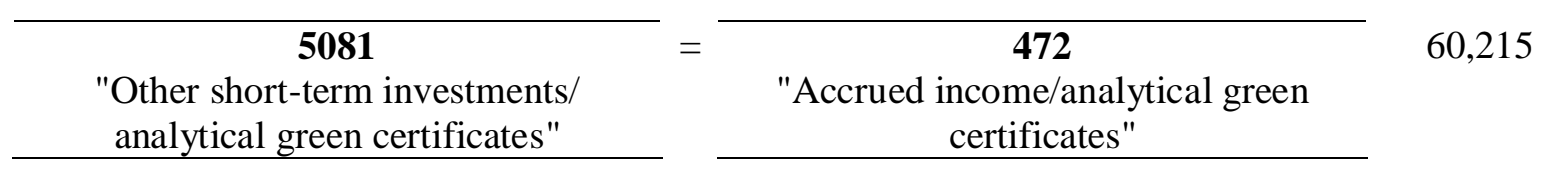

2. SC Energoplus SA is selling to a client 100 green certificates at a price of 243.27 lei/certificate (higher than the accounting value of 240.86 lei). This transaction takes place in October 2012:

- sale of green certificates:

\begin{tabular}{ccc}
\hline $\mathbf{4 6 1}$ & $\begin{array}{c}\% \\
\text { "Sundry debtors" }\end{array}$ & $\mathbf{2 4 , 3 2 7}$ \\
\hline
\end{tabular}




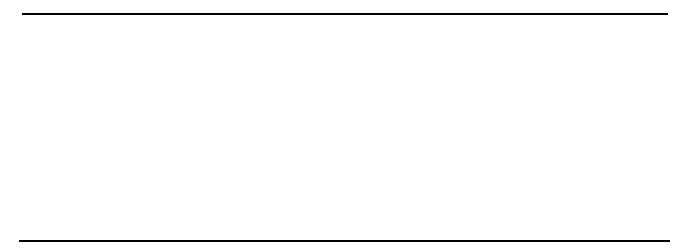

\begin{tabular}{c}
\hline "Other short-term investments/ \\
analytical green certificates" \\
$\mathbf{7 6 4 2}$ \\
"Gains on disposal of short-term \\
investments" \\
\hline
\end{tabular}

- resumption to income of the share of accrued income:

$\mathbf{4 7 2}$
"Accrued income/analytical green
certificates"

$\overline{\mathbf{7 6 4 2}}$
"Gains on disposal of short term
investments"

3. For a sale price of 238.12 lei/certificate (less than the accounting value of 240.86 lei), the first accounting formula is changing as follows:

\begin{tabular}{ccr}
\hline $\begin{array}{c}\mathbf{4 6 1} \\
\text { "Sundry debtors" } \\
\mathbf{6 6 4 2}\end{array}$ & $\begin{array}{c}\mathbf{5 0 8 1} \\
\text { "Other short-term investments/ } \\
\text { analytical green certificates" }\end{array}$ & $\mathbf{2 3 , 8 1 2}$ \\
$\begin{array}{c}\text { Losses disposal of short-term } \\
\text { investments" }\end{array}$ & & 174 \\
\hline
\end{tabular}

4. At the end of the financial year 2012, SC Energoplus SA evaluates the 150 green certificates using trading value communicated by SC OPCOM SA for the last transaction that is 244 lei/certificate:

\begin{tabular}{ccc}
\hline $\mathbf{5 0 8 1}$ & $=$ & $\mathbf{7 6 8}$ \\
$\begin{array}{c}\text { "Other short-term investments/ } \\
\text { analytical green certificates" }\end{array}$ & "Other financial incomes" \\
\hline
\end{tabular}

5. For a trading value of 238 lei/certificate, announced by SC OPCOM SA for last transaction, at the end of the financial year 2012, SC Energoplus SA records in accounting an expenditure:

\begin{tabular}{ccc}
\hline $\mathbf{6 6 8}$ & $=\begin{array}{c}\mathbf{5 0 8 1} \\
\text { "Other financial expenses" }\end{array}$ & $\begin{array}{c}\text { "Other short-term investments/ } \\
\text { analytical green certificates" }\end{array}$ \\
\hline
\end{tabular}

\section{B. The accounting treatment of green certificates applicable to electricity providers}

1. In august 2012, SC EnergieHidro SA bought from SC OPCOM SA 450 green certificates for a price of 240.86 lei/certificate. Acquisition takes place in legal time limits:

\begin{tabular}{ccc}
\hline $\begin{array}{c}\mathbf{6 5 2} \\
\begin{array}{c}\text { Expenses related to environment } \\
\text { protection" }\end{array}\end{array}$ & $\begin{array}{c}\mathbf{4 0 1} \\
\text { "Suppliers" }\end{array}$ & 108,387 \\
\hline
\end{tabular}

2. For an acquisition of green certificates before legal time limits, the record in accounting of SC EnergieHidro SA is: 


\begin{tabular}{c}
\hline $\mathbf{4 7 1}$ \\
"Prepayments" \\
\hline
\end{tabular}

\begin{tabular}{cc}
\hline $\mathbf{4 0 1}$ \\
"Suppliers" \\
\hline
\end{tabular}

108,387

- at legal time limits, SC EnergieHidro SA is recording the acquisition of green certificates as follows:

$652=$

"Expenses related to environment protection"

$\begin{array}{cc}\mathbf{4 7 1} & 108,387\end{array}$

"Prepayments"

C. The accounting treatment of green certificates applicable to entities who buy green certificates in order to obtain short-term gains

1. In August 2012, SC Alfa SA bought 120 green certificates for a price of 240.86 lei/certificate. SC Alfa SA is not an electricity provider, but decided acquisition of the titles to obtain short-term profit:

\begin{tabular}{ccc}
\hline $\begin{array}{c}\mathbf{5 0 8 1} \\
\begin{array}{c}\text { "Other short-term investments/ } \\
\text { analytical green certificates" }\end{array}\end{array}$ & $\begin{array}{c}\mathbf{4 0 1} \\
\text { "Suppliers" }\end{array}$ & 28,903.2 \\
\hline
\end{tabular}

2. In December 2012, SC Alfa SA evaluates the 120 green certificates using trading value communicated by SC OPCOM SA for the last transaction that is 244 lei/certificate:

\begin{tabular}{ccc}
\hline $\begin{array}{c}\mathbf{5 0 8 1} \\
\begin{array}{c}\text { "Other short-term investments/ } \\
\text { analytical green certificates" }\end{array}\end{array}$ & "Other financial incomes" & $\mathbf{7 6 8}$ \\
\hline
\end{tabular}

3. In January 2013, SC Alfa SA sold 80 green certificates at a price of 245.12 lei/certificate:

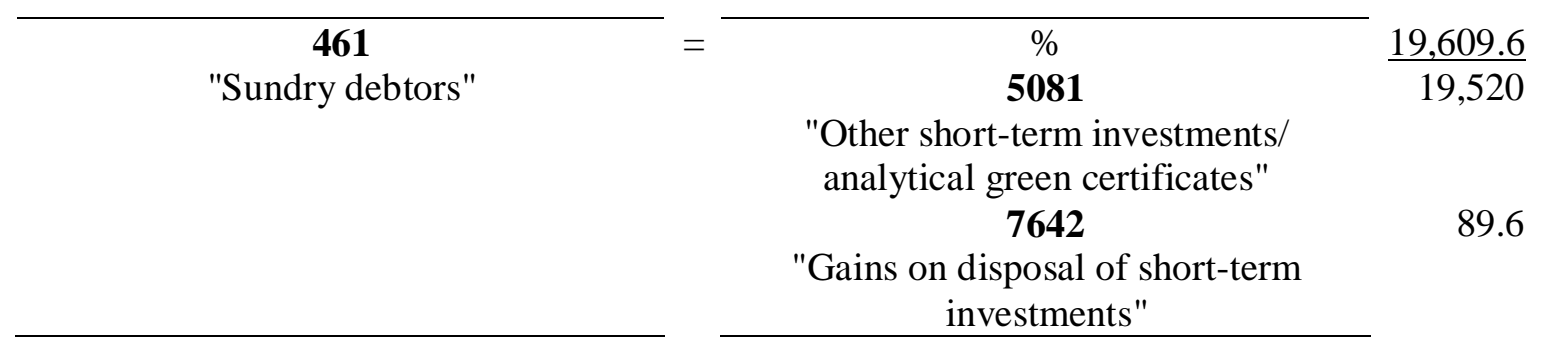

4. SC Alfa SA cancel the 40 green certificates unused in validity period:

$668=\overline{5081} \quad 9,760$

"Other financial expenses" "Other short-term investments/ analytical green certificates" 


\section{Conclusions}

Worldwide, the production of electricity from renewable energy sources is gaining more ground at the expense of non-renewable sources. The emergence of a system of certificates related to energy from renewable sources required creating a green certificates market, where the owners' offer of such titles, and the demand expressed for them could meet.

At the national level, to encourage electricity production from renewable energy sources in Romania, by Government Decision no. 1892/2004, it was established a system of promotion of electricity production from renewable energy sources. The system for the promotion of electricity production from renewable energy sources adopted is that of mandatory quotas combined with the trading system of green certificates. By the Energy Strategy of Romania for the period 2007-2020, approved by Government Decision no. 1069/2007, Romania has assumed as strategic objectives the national targets for the share of electricity produced from renewable energy sources in final consumption of electricity in the years 2010, 2015 and 2020, respectively, 33\%, 35\% and 38\%.

Currently, accounting treatment of green certificates is regulated by Minister of Public Finance Order no. 3055/2009, as amended by Minister of Public Finance Order no. 1118/2012. Until the emergence of the latter, the accounting treatment of green certificates was specific to greenhouse gas emission certificates. By Minister of Public Finance Order no. 1118/2012 it was regulated the entry mode in the accounts of green certificates for both renewable energy producers, as well as suppliers and producers of electricity required to purchase green certificates. By the new accounting regulations, the accounting treatment for the greenhouse gas emission certificates is also presented. Thus, the greenhouse gas emission certificates bought for long term profit stands distinctly under other investments held as fixed assets, while the certificates purchased for obtaining profit from the sale in a short period of time are outlined under other short-term investments.

Achieving the objectives set by the authors of this study required in advance, making a comparative analysis of records of transactions with green certificates based on the accounting treatment prescribed by the authors who examined this issue. For this, we structured the data in a table which revealed the accounting formulas for each operation, stage accompanied by assessments made on the basis of the findings. In this context, the research requires a careful analysis of accounting regulations in force relating to the accounting of green certificates, but also the previous accounting rules in the context of the dynamics of accounting.

The research results consist in presenting the accounting treatment applicable to green certificates for producers of electricity from renewable sources, which benefit from these titles, as well as for providers and producers of electricity who are required to purchase green certificates by one numerical example. The difficulties encountered in achieving the goal of this paper were given by the insufficient information provided in the accounting regulations in force at the moment and the confusions in the researched literature, and the absence of other explanations in a guide prepared by the accounting standard-setting institution.

At the end of April 2013, on the green certificates market were enrolled 322 participants (suppliers and producers), and until May 15 were traded 235,687 titles on the green certificates centralized market and 1,186,978 titles on bilateral contracts market for green certificates (OPCOM, Press release, 2013). All these entities need for recording the green certificates an accounting treatment. This explains the usefulness of the research undertaken.

Future research on green certificates aim at analyzing the level and dynamics of income and expenditure in green certificates at a national level, but also in European and international context, analyzing the tax treatment of income and expenditure in green certificates in the stated conditions under the tax rules represented by Law no. 571/2003 regarding the Fiscal Code, as amended and supplemented, and the implementing Rules of the Tax Code, approved by Government Decision no. $44 / 2004$, as amended and supplemented. Another line of research concerns the analysis of accounting and tax treatment of greenhouse gas emission certificates. 


\section{References}

1. Bărbătescu N., 2012. Tratament contabil aplicabil certificatelor verzi, [Online] available at http://contabarbatescu.blogspot.ro/, accessed on February 6, 2013

2. Benta A., 2012. Reglementările contabile aprobate prin Ordinul 3055/2009 au fost modificate de MFP, [Online] available at http://legestart.ro/reglementarile-contabileaprobate-prin-ordinul-30552009-au-fost-modificate-de-mfp/, accessed on January 21, 2013.

3. Bețianu L., 2009. Calitate totală în contabilitatea mediului, „Alexandru Ioan Cuza” University Publishing House, Iaşi

4. Dunel-Stancu D., 2011. Despre certificate verzi, aer curat şi bani în vânt, [Online] available at http://blog.legestart.ro/despre-certificate-verzi-aer-curat-si-bani-in-vant/, accessed on January 16, 2013.

5. Garaiman R., 2013. Câşstigă bani din energia regenerabilă! Cum funcționează sistemul certificatelor verzi, [Online] available at http://www.business24.ro/energie/certificateverzi/castiga-bani-din-energia-regenerabila-cum-functioneaza-sistemul-certificatelor-verzi1523620, accessed on January 16, 2013.

6. Ienciu I.A., 2009. Implicațiile problemelor de mediu în contabilitatea şi auditul de mediu, Risoprint Publishing House, Cluj Napoca

7. Neagu R., 2012. Reguli noi de contabilitate aplicabile din 2013 pentru situațiile financiare anuale, [Online] available at http://www.medierenet.ro/2012/10/03/reguli-noi-decontabilitate-aplicabile-din-2013-pentru-situatiile-financiare-anuale/, accessed on January 11, 2013.

8. Nuță F.M., 2009. Contabilitatea protecției mediului în economia contemporană, „Alexandru Ioan Cuza" University Publishing House, Iaşi.

9. Pântea I.P., Bodea Gh., 2013. Contabilitate financiară, Intelcredo Publishing House, Deva.

10. Staicu E., 2012. Se modifică unele reglementări contabile privind operațiunile cu certificate verzi, [Online] available at http://legestart.ro/update-se-modifica-unele-reglementaricontabile-privind-operatiunile-cu-certificate-verzi/, accessed on January 21, 2013.

11. ***, 2012. Contabilitatea certificatelor verzi, [Online] available at http://www.nexusmedia. ro/arttehnice.php?id=103, accessed on January 21, 2013.

12. ***, 2012. Modificările aduse Tratamentului Contabil şi Fiscal al Certificatelor de Emisii de Gaze cu Efect de Seră, KPMG Advisory Newsflash no. 141, [Online] available at http://www.kpmg.com/RO/en/IssuesAndInsights/ArticlesPublications/Newsflashes/Advisor y/Advisory-Newsflash/Documents/RNF_141_RO.pdf, accessed on January 11, 2013.

13.***, 2012. Noi reguli de contabilitate pentru certificatele verzi, [Online] available at http://cdexecutive.blogspot.ro/2012/10/noi-reguli-de-contabilitate-pentru.html, accessed on January 18, 2013.

14.***, 2012. Reguli contabile privind operațiuni cu certificate verzi, [Online] available at http://auditeam.ro/reguli-contabile-privind-operatiuni-cu-certificate-verzi.html, accessed on February 2, 2013.

15.***, 2012. Tratament contabil aplicabil certificatelor verzi, [Online] available at http://contabilul.manager.ro/a/7704/tratament-contabil-aplicabil-certificatelor-verzi.html, accessed on January 18, 2013.

16. ***, Legea $\mathrm{nr}$. 220/2008 pentru stabilirea sistemului de promovare a producerii energiei din surse regenerabile de energie, republished in Monitorul oficial nr. 577/2010, amended and supplemented.

17. ***, Legea energiei electrice şi a gazelor naturale nr. 123/2012, published in Monitorul Oficial no. 485/2012. 
18. ***, Hotărârea de Guvern nr. 1892/2004 pentru stabilirea sistemului de promovare a producerii energiei electrice din surse regenerabile de energie, published in Monitorul Oficial no. 1056/2004, amended.

19. ***, Hotărârea de Guvern nr. 780/2006 privind stabilirea schemei de comercializare a certificatelor de emisii de gaze cu efect de seră, published in Monitorul Oficial no. 554/2006, amended and supplemented.

20. Hotărârea de Guvern nr. 1069/2007 privind aprobarea Strategiei energetice a României pentru perioada 2007-2020, published in Monitorul Oficial no. 781/2007.

21. Ordinul ministrului Finanțelor Publice nr. 94/2001 pentru aprobarea Reglementărilor contabile armonizate cu Directiva a IV-a a Comunităților Economice Europene şi cu Standardele Internaţionale de Contabilitate, published in Monitorul Oficial no. 85/2001, amended and supplemented.

22. Ordinul ministrului Finanțelor Publice nr. 1752/2005 pentru aprobarea Reglementărilor contabile conforme cu directivele europene, published in Monitorul Oficial no. 1080/2005, amended and supplemented.

23. Ordinul ministrului Finanțelor Publice nr. 3055/2009 pentru aprobarea Reglementărilor contabile conforme cu directivele europene, published in Monitorul Oficial no. 766/2009, amended and supplemented.

24. Ordinul preşedintelui Autorității Naționale de Reglementare în Domeniul Energiei nr. 43/2011 pentru aprobarea Regulamentului de emitere a certificatelor verzi, published in Monitorul Oficial no. 768/2011.

25. Ordinul preşedintelui Autorității Naţionale de Reglementare în Domeniul Energiei nr. 44/2011 pentru aprobarea Regulamentului de organizare şi funcționare a pieței de certificate verzi, published in Monitorul Oficial no. 784/2011.

26. Ordinul preşedintelui Autorităţii Naţionale de Reglementare în Domeniul Energiei nr. 45/2011 pentru aprobarea Metodologiei de stabilire a cotelor anuale de achiziţie de certificate verzi, published in Monitorul Oficial no. 769/2011.

27. OPCOM, 2013. Comunicat de presă, [Online] available at http://www.opcom.ro/opcom/ uploads/doc/Comunicate/20130416_RO.pdf, accessed on May 21, 2013

28. OPCOM, 2013. Comunicat de presă, [Online] available at http://www.opcom.ro/opcom/ uploads/doc/Comunicate/20130509_RO.pdf, accessed on May 21, 2013.

29. http://clubcontabilitate.manager.ro/studii-de-caz/certificate-verzi-995.html

30. http://www.opcom.ro/opcom/anunturi_stiri/anunturi_pcv.php?id_piata=4\&lang=ro

31. http://www.conta.ro/forum/topic/46299-inregistrare-certificate-verzi-la-factura-de-energieelectrica/

32. http://www.opcom.ro/tranzactii_produse/tranzactii_produse.php?lang=ro\&id=34

33. http://www.opcom.ro/opcom/uploads/doc/PCCV/PCV_Descriere.pdf 